Brazilian Journal

of Chemical

ISSN 0104-6632

Engineering

\title{
EVALUATION OF LIMESTONE IMPURITIES IN THE DESULFURIZATION PROCESS OF COAL COMBUSTION GAS
}

\author{
F. de Souza and S. R. Bragança* \\ Federal University of Rio Grande do Sul, Av. Osvaldo Aranha, 99/711, \\ CEP: 900135-190, Porto Alegre - RS, Brazil. \\ Phone: + 5551 3308-3594; Fax: + 5551 3308-3405 \\ E-mail: saulorb@ufrgs.br
}

(Submitted: March 12, 2015 ; Revised: September 9, 2015 ; Accepted: December 21, 2015)

\begin{abstract}
Limestones have been used to capture $\mathrm{SO}_{2}$ emitted during the combustion of coal for decades. However, due to the complexities of the variables involved in this process, many issues are still being studied. Some tests were performed in a fluidized bed reactor, which was used to evaluate the performance of the limestones in the bed for flue gas desulfurization, burning low sulfur coal. Metamorphic dolomitic limestones of low cost were evaluated considering the impurity level and need for beneficiation. They were characterized chemically, physically and microstructurally (X-ray fluorescence, X-ray diffraction, laser particle size analyzer, scanning electronic microscope). The data obtained were compared to a calcitic limestone of elevated purity and higher market value. The results showed little effect of the major impurities present in the dolomitic limestones in the calcination and desulfurization processes. Microcrystalline impurities showed a marked effect promoting grain sintering in calcination conditions of TGA/DTA tests in different atmospheres, as shown in SEM images. Dolomitic limestones generate more solid waste and capture less $\mathrm{SO}_{2}$ per $\mathrm{kcal}(\mathrm{a}$ slightly decrease in the thermal efficiency of the reactor) compared to calcitic limestones. However, due to the lower cost, they were considered to be attractive for the $\mathrm{FBC}$ process $(2 \mathrm{mg} \mathrm{SO} / \mathrm{kcal} \mathrm{at} \mathrm{Ca} / \mathrm{S}=3)$.

Keywords: Limestones; Impurities; Calcination; Desulfurization; Oxy-combustion.
\end{abstract}

\section{INTRODUCTION}

Limestones are injected into the combustor chamber of boilers and furnaces at firing temperatures above the temperature of $\mathrm{CaCO}_{3}$ calcination. This compound immediately decomposes to $\mathrm{CaO}$, which reacts with the $\mathrm{SO}_{2}$ to form a solid, relatively stable product - calcium sulfate $\left(\mathrm{CaSO}_{4}\right)$. The abundance and low cost of limestone explain its wide use as a means of controlling sulfur emissions. Regenerable sorbents, considering the cost, have not yet become competitive, and their commercial use is restricted (Anthony, 2001).

Calcitic and dolomitic limestones are the main sorbents used for the removal of sulfur compounds (SOx) emitted in the combustion of coal in power generation. The future installation of a thermoelectric plant using fluidized bed technology in southern Brazil, a region of huge coal reserves, is expected. The fact that this plant will use limestone as a sorbent of sulfur emissions boosted this study (CGTEE, 2014; CRM, 2014). However, there are mainly dolomitic limestones in the region, which exhibit a strong variation in the content of impurities depending on the deposit from which they are extracted (Moraes, 1996).

Characterization of limestones encompasses chemical and mineralogical analyses, which are very

*To whom correspondence should be addressed 
important in the differentiation of the chemical composition and minerals present, among different types of rocks. The physical properties such as particle size, surface area, pore volume and the description of the texture with microscopic techniques are generally used in the analysis of the raw materials. However, carbonate minerals have similar physical properties, and it is difficult to distinguish them in different limestones (Luz, 2005). An adequate characterization is needed for better understanding of the properties most important to desulfurization. It is noted that contradictory results can be found in the literature about the performance of calcitic and dolomitic limestones. Depending on the experimental conditions and/or limestone origin, the efficiency of desulfurization may change. It is possible to find experimental results in which calcitic and dolomitic limestones change places as being indicated as the best sorbent (Montagnaro, 2010; Kaljuvee, 2005; Laursen, 2000; De Diego, 2013a). A dolomite showed superior performance as sorbent for $\mathrm{CO}_{2}$ capture in a postcombustion system due to higher $\mathrm{MgO}$ resistance to sintering that stabilizes $\mathrm{CaO}$ structure (Valverde, 2015).

The influence of the impurities present in limestone rock, such as silica, salts and oxides of alkali metals, on the desulfurization process is still an object of doubt in the literature. Moreover, the performance of limestone-type regarding the content of magnesium oxide, as previously mentioned, is also in dispute. Different information can be found:

- The formation of eutectic compounds reduces the melting temperature, increasing the reactivity of the limestone, by forming a liquid phase, which causes an expansion and increased intraparticle pore diffusion (Han, 2005).

- The specific surface area available for reaction is reduced by increasing the sintering ( $\mathrm{Hu}, 2006)$. Chen (2012) demonstrated that, even impurities originating from coal combustion ( $\mathrm{Al}$ and $\mathrm{Si}$ ) can be detrimental due to the preferential formation of eutectic calcium aluminosilicate, thus reducing the amount of calcium available for desulfurization. Impurities such as iron and aluminum oxides tend to produce lower surface areas in both the limestones and their calcines (Trikkel, 2005).

Recent studies in oxy-combustion conditions have presented new questions about the use of limestones, because the differences in the firing atmosphere of the fuel significantly affect the $\mathrm{SO}_{2}$ retention process. Thus, issues such as the influence of firing temperature, gas concentration and attrition of limestone in the bed, for example, come into contention. Furthermore, the sulfation mechanism can change, since direct sulfation of the carbonate can occur, and at higher temperatures, indirect sulfation may prevail (Montagnaro, 2010; De Diego, 2013a; Chen, 2012). The analysis of published data shows that the optimum desulfurization temperature changes from $850{ }^{\circ} \mathrm{C}$ to $\sim 920^{\circ} \mathrm{C}$ (De Diego, 2013; Las ObrasLoscertales, 2013). In general, emissions of NO, $\mathrm{N}_{2} \mathrm{O}$ and $\mathrm{CO}$ do not change in the conditions of oxycombustion (De Diego, 2013b). Due to research on climate change, the new trend is on more restriction of emissions of carbon dioxide, aiming at zero emissions (IPCC, 2014). Consequently, the use of oxycombustion technology must be the future choice as a mean of continuing to use coal.

In the present study, dolomitic limestones are tested as $\mathrm{SO}_{2}$ sorbents, comparing them with a calcitic limestone of higher purity. As it is known, dolomitic limestones are not suitable for the cement industry and have a low market value; therefore, due to their lower price, they are more attractive as sorbents than calcitic limestones. The physicochemical characterization was carried out, seeking to relate limestone properties with the performance in desulfurization. In addition, the use of a limestone of very high impurity content, which is run of mine (very low commercial cost), was analyzed. The issue of the need of mineral beneficiation for the purification of this limestone (or the use with its impurities) is analyzed from an economic and technical point of view. Tests in a fluidized bed reactor were also realized to validate the use of these limestones.

\section{MATERIALS AND METHODS}

The limestones used in this work are metamorphic rocks, and were classified as marble-serpentine, according to a previous study (Moraes, 1996). A dolomite (Do), two dolomitic limestones (D1 and $\mathrm{D} 2)$, one calcitic dolomite $(\mathrm{Cd})$ and a calcitic limestone (C), from southern Brazil, were tested. For simplification, all the sorbents are treated as limestone and were classified using Petijohn's nomenclature (Petijohn, 1957). The potential use of Cd limestone with a high content of impurities, from the same geological deposit of D2, but without any treatment except grinding (run of mine) was investigated. $\mathrm{Cd}$ limestone was studied in parallel with the processed limestone D2 and with a high purity limestone (limestone C) in order to contrast the characterization analyses, comparatively, by studying in detail the presence and type of the impurities.

In the second part of the study, tests were performed in an atmospheric fluidized bed reactor using 
the D1 limestone and the dolomite Do, which are usually on the market. They have different amounts of $\mathrm{MgO}$ and $\mathrm{CaO}$, but approximated the same weight loss on ignition (LOI). Gaseous emissions were monitored continuously using an infrared analyzer (MIR 9000 - emissión s.a.). The coal used is from the Candiota-RS mine - coal reserves of approximately one billion tons. Combustion tests were carried out in a cylindrical stainless steel reactor (belonging to the Fundação de Ciência e Tecnologia - CIENTEC-RS), bench scale, and coated externally with glass wool, with an electric heating system for the initial heating up. The cross section of the bed is $177 \mathrm{~cm}^{2}$ and the coal processing capacity is $5 \mathrm{~kg} / \mathrm{h}$. Coal combustion emissions: $\mathrm{SO}_{2} 900$ ppm; $\mathrm{CO} 150$ ppm; $\mathrm{CO}_{2} 6 \%$. The limestone is mixed with the coal prior to injection into the reactor, directly in the combustion chamber, by a screw feeder system and auxiliary air. Minimum fluidization velocity: Limestone $(0.042$ $\mathrm{cm})=19.1 \mathrm{~cm} / \mathrm{s}$; coal $(0.074 \mathrm{~cm})=29.7 \mathrm{~cm} / \mathrm{s}$. Experimental conditions and coal analyses are shown in Table 1. The reactor scheme is shown in Figure 1.

The chemical and mineralogical compositions of the limestones were analyzed by X-ray fluorescence (Shimadzu spectrometer, XRF - 1800) and X-ray diffraction (Philips X'Pert), respectively. A laser particle size analyzer (Cilas, Model 1180) was used to determine the particle size. Microstructural analysis was carried out by SEM on a Hitachi 3000 with EDS probe.

Table 1: Candiota coal analyses and reactor experimental conditions (atmospheric pressure).

\begin{tabular}{|c|c|c|c|}
\hline $\begin{array}{l}\text { Proximate } \\
\text { analysis }\end{array}$ & & Plant scale & Bench \\
\hline $\begin{array}{l}\text { Fixed carbon } \\
(\%)\end{array}$ & 25.1 & Temperature & $850^{\circ} \mathrm{C}+/-5^{\circ} \mathrm{C}$ \\
\hline $\begin{array}{l}\text { Volatile matter } \\
(\%)\end{array}$ & 18.7 & $\begin{array}{l}\text { Bed initial } \\
\text { material }\end{array}$ & $\begin{array}{r}\text { Sand }(\text { mean } \\
\text { size } 0.04 \mathrm{~cm})\end{array}$ \\
\hline Ash (\%) & 56.2 & $\begin{array}{l}\text { Cross section } \\
\text { area }\end{array}$ & $177 \mathrm{~cm}^{2}$ \\
\hline $\begin{array}{l}\text { Ultimate } \\
\text { analysis }\end{array}$ & & Reactor height & $120 \mathrm{~cm}$ \\
\hline Carbon (\%) & 31.6 & $\begin{array}{l}\text { Bed height } \\
\text { (sand) } \\
\text { Static/Expanded }\end{array}$ & $\begin{array}{l}15 \mathrm{~cm} \\
40 \mathrm{~cm}\end{array}$ \\
\hline Hydrogen (\%) & 2.1 & $\begin{array}{l}\text { Gas residence } \\
\text { time }\end{array}$ & $0.6 \mathrm{~s}$ \\
\hline $\begin{array}{l}\text { Oxygen and } \\
\text { others }(\%)\end{array}$ & 8.3 & Air flow & $21 \mathrm{~kg} / \mathrm{h}$ \\
\hline Nitrogen (\%) & 0.7 & Air velocity & $67 \mathrm{~cm} / \mathrm{s}$ \\
\hline Sulfur (\%) & 1.1 & Air excess & $+/-190 \%$ \\
\hline Moisture (\%) & 11.7 & $\begin{array}{l}\mathrm{O}_{2} \text { in exhaust } \\
\text { gas }\end{array}$ & $12 \%$ \\
\hline $\begin{array}{l}\text { Gross } \\
\text { C.V. }(\mathrm{kJ} / \mathrm{kg})\end{array}$ & 11.9 & Coal flow & $2 \mathrm{~kg} / \mathrm{h}$ \\
\hline
\end{tabular}

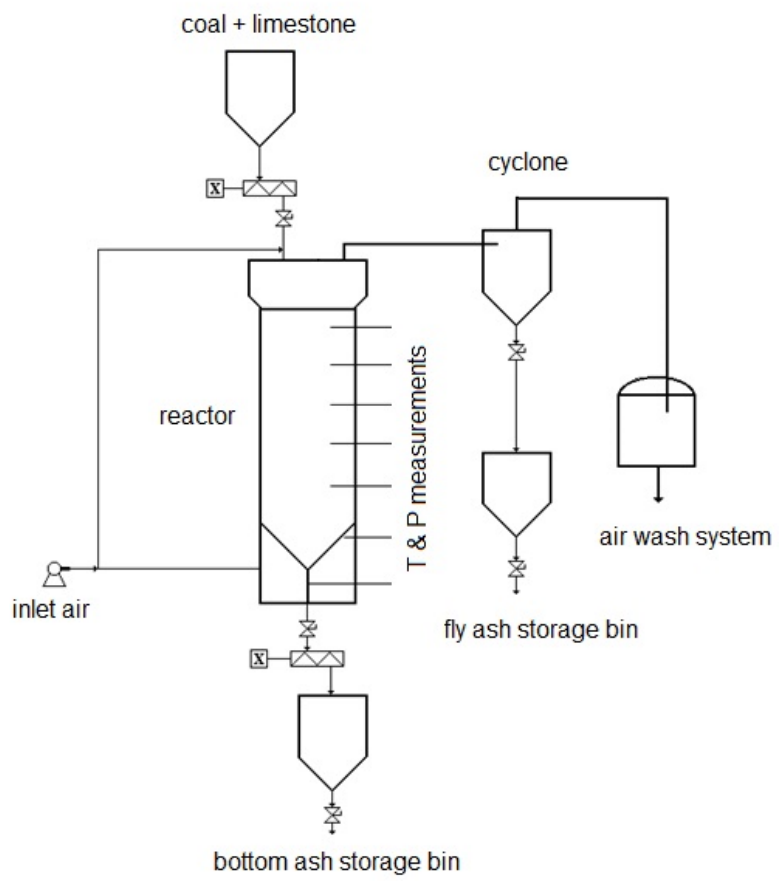

Figure 1: Reactor scheme.

Tests in the thermobalance (Mettler Toledo TGA/ DTA 851e) were performed between $20-1200{ }^{\circ} \mathrm{C}$ at a heating rate of $10 \mathrm{~K} / \mathrm{min}$ and with a gas flow rate of $10 \mathrm{~mL} / \mathrm{min}$ (NTP) in an atmosphere of pure $\mathrm{O}_{2}, 12 \%$ $\mathrm{CO}_{2}+$ synthetic air (furnace conditions) and $80 \%$ $\mathrm{CO}_{2}+20 \% \mathrm{O}_{2}$ (oxy-combustion conditions). The synthetic gases were supplied by Linde Industrial Gases.

\section{RESULTS AND DISCUSSION}

\section{Characterization of Limestones as Raw Material}

Table 2 shows the limestone chemical compositions. C limestone is mainly composed of calcite, without dolomite (as can be seen in X-ray diffraction analysis), and the content of other phases is below the minimum level of the equipment detection. This is in agreement with the chemical composition analysis (impurities $<0.7 \%$ and no $\mathrm{MgO}$ ). The other limestones investigated have calcite and dolomite, with the presence of quartz and clay minerals. $\mathrm{Cd}$ has the highest content of impurities, mainly silica, which is $\sim 21.5 \%$. Figure 2 shows the mineral phases of Cd (showing as major impurities quartz, kaolinite and muscovite), D2 (lower levels of impurities than $\mathrm{Cd}$, but the same kind of impurities, quartz, kaolinite and muscovite), and $\mathrm{C}$ (no detectable impurities). 
Table 2: Chemical composition, mineral phases and particle size of the limestones Do, D1, D2, Cd and C.

\begin{tabular}{|c|c|c|c|c|c|}
\hline Compounds (\%) & Do & D1 & D2 & Cd & $\mathbf{C}$ \\
\hline $\mathrm{CaO}$ & 29.00 & 42.62 & 37.40 & 35.23 & 56.60 \\
\hline $\mathrm{MgO}$ & 19.52 & 5.61 & 10.53 & 10.93 & - \\
\hline $\mathrm{SiO}_{2}$ & 13.54 & 10.27 & 12.38 & 21.46 & 0.40 \\
\hline $\mathrm{Al}_{2} \mathrm{O}_{3}$ & 0.56 & 1.84 & 1.44 & 2.47 & 0.21 \\
\hline $\mathrm{Fe}_{2} \mathrm{O}_{3}$ & 0.86 & 0.88 & 0.65 & 1.14 & 0.07 \\
\hline $\mathrm{Na}_{2} \mathrm{O}$ & 0.02 & 0.14 & - & - & - \\
\hline $\mathrm{K}_{2} \mathrm{O}$ & 0.08 & 0.74 & 0.36 & 0.51 & 0.04 \\
\hline Others & 0.08 & 0.18 & 0.04 & 0.11 & - \\
\hline LOI (\%) & 36.18 & 37.42 & 37.20 & 28.16 & 43.20 \\
\hline$\sum$ impurities* & 15.14 & 14.05 & 14.89 & 25.69 & 0.74 \\
\hline Mean Particle size (mm) & 0.350 & 0.410 & 0.484 & 0.444 & 0.422 \\
\hline Major phases (DRX) & $\begin{array}{l}\text { Calcite and } \\
\text { Dolomite }\end{array}$ & $\begin{array}{c}\text { Calcite and } \\
\text { Dolomite }\end{array}$ & $\begin{array}{l}\text { Calcite and } \\
\text { Dolomite }\end{array}$ & $\begin{array}{c}\text { Calcite and } \\
\text { Dolomite }\end{array}$ & Calcite \\
\hline
\end{tabular}

*Obs: all oxides without $\mathrm{CaO}$ and $\mathrm{MgO}$.
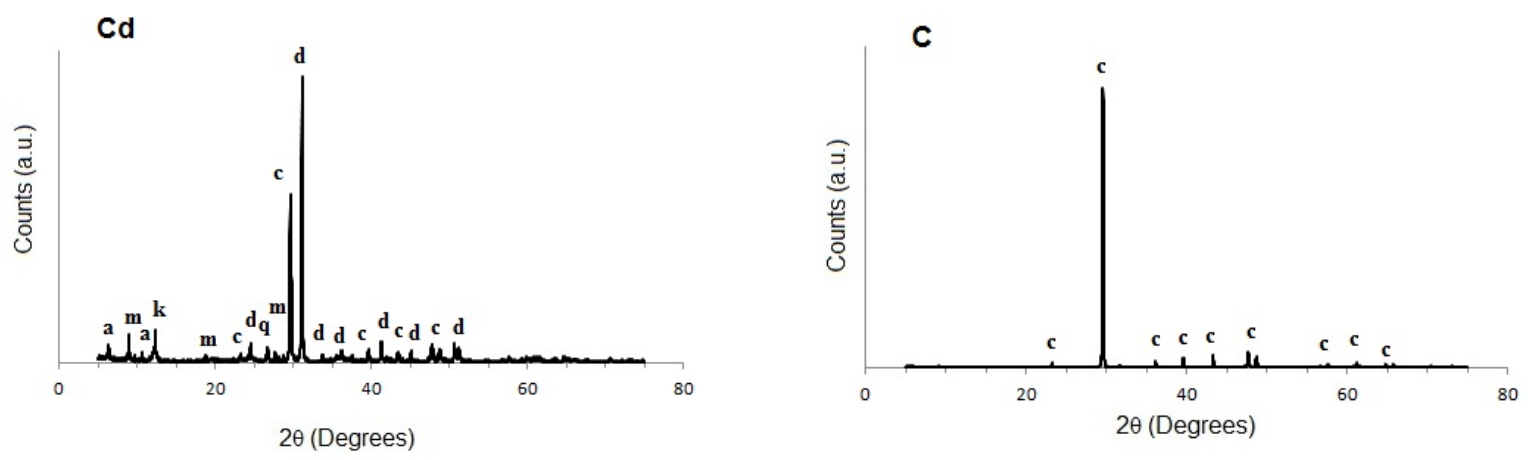

D2

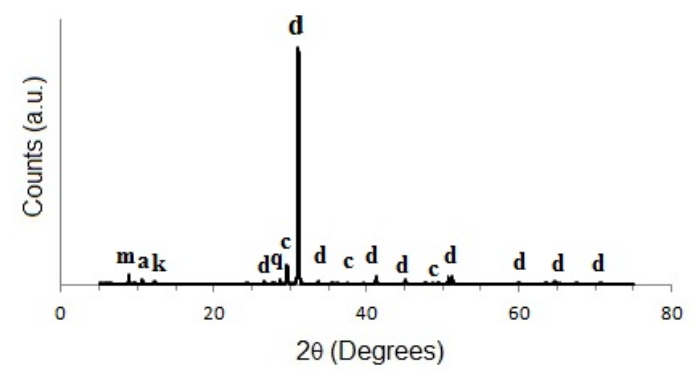

Figure 2: XRD limestones Cd, D2, and C. a: aluminosilicate; c: calcite; d: dolomite; m: muscovite; k: kaolinite; q: quartz.

Figures 3 and 4 show the distribution of impurities in the limestone particles $(\mathrm{Cd})$. Impurities may have little influence on calcination/desulfurization, because it is possible to find them separated from the limestone particles as shown in Figure 3 and Figure 4 (e.g., particle with high content of silicon). This type of impurity may have good potential to be separated by a simple mineral beneficiation process, e.g., quartz has higher hardness than limestone, so it tends to concentrate as the coarser fraction in gravimetric processing (simple grinding and sieving). Moreover, the need to remove it is questionable, because in general the reactor bed is periodically fed with sand (a quartz-rich rock).

Part of the impurities and the limestone phase share the same particles (Figures 3 and 4), as the milling time/efficiency was not enough to break them up, and to separate them. It may have some influence on calcination and desulfurization. The impurities are in direct contact with the limestone grains in the particle, possibly decreasing the area of contact with the reaction gas. However, the thermal shock that the particles suffer when entering into the bed, and even the porosity developed in calcination, can minimize this effect (the loss of surface area). 


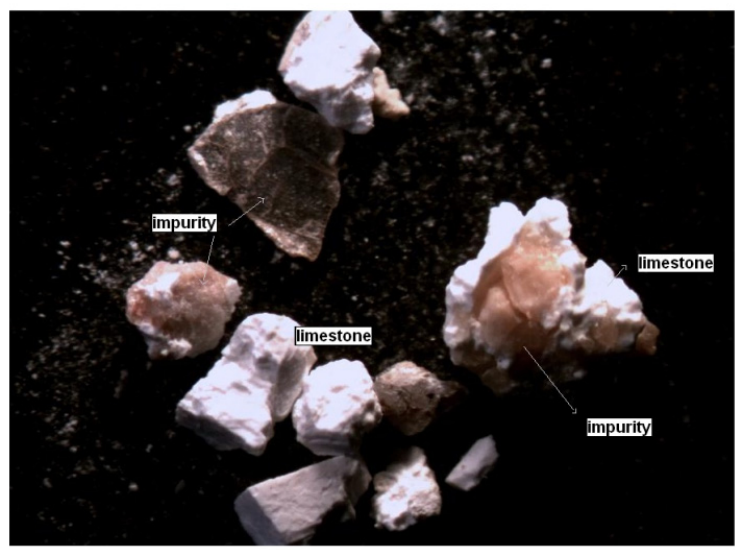

Figure 3: Optical micrograph of limestone $\mathrm{Cd}$ showing the presence of impurities.
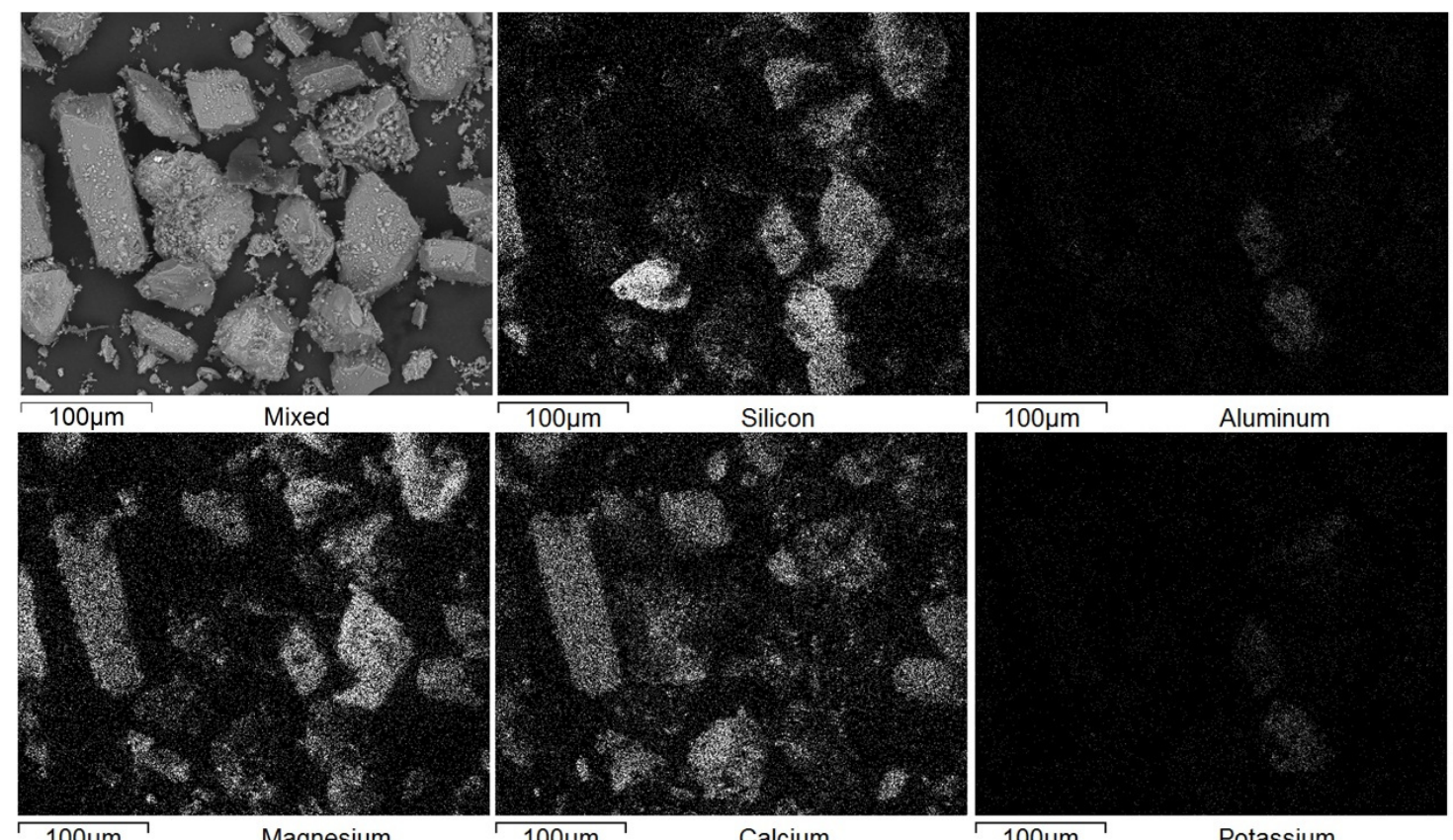

$100 \mu \mathrm{m} \quad$ Magnesium

$100 \mu \mathrm{m}$

Calcium

Potassium

Figure 4: SEM images and EDS mappings of Cd limestone.

The most important impurities are microcrystalline phases because they can act as fluxes, providing the local melting or sintering of the raw material and potentially decreasing the porosity (Chen, 2012). As a result, the loss of specific area decreases the desulfurization efficiency. Another study states that the impurities present in the limestone may have little influence on the process, depending on the reactor operating conditions (Anthony, 2001). This author concluded that there is no consensus about the role of impurities in desulfurization, so that investigations are required before the industrial use of the limestones.
Therefore, although some limestone rocks have a high content of impurities, as shown in Cd, they may have a good potential for use in desulfurization, especially due to their low cost in the market. In addition, this cost can be further reduced by eliminating or simplifying the gravimetric process and the materials preparation step.

In general, limestone rocks exhibit a compact surface with pores on some particle surfaces, and the presence of fractures originating from the rock extraction process and milling, as can be seen in Figure 5. Particle shape is very irregular, but rounded particles can be observed as a consequence of ball mill- 
ing. One can also observe the rhombohedral morphology which is characteristic of calcite and dolomite crystals. Although a relationship between the morphology and microstructure of the limestone rock with sulfur capture efficiency could be expected, no such study has shown it due to changes occurring in calcination (Laursen, 2000; Anthony, 2001). After calcination, the $\mathrm{CaO}$ generated has a structure which is completely different from that of the parent rock.
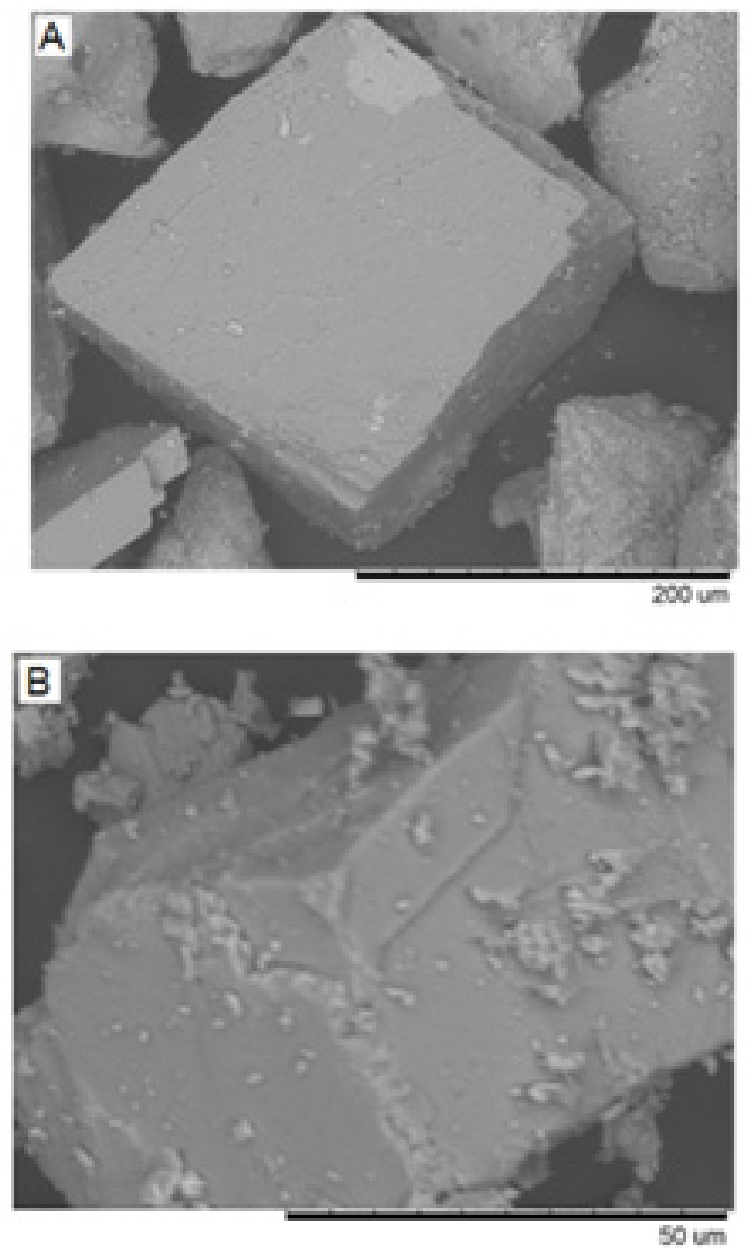

Figure 5: SEM. A) limestone Cd. B) limestone C.

\section{Calcination in the Thermobalance}

The analysis of the calcination in the thermobalance (TGA/DTA) was performed on samples of similar mean particle size (Cd, C, and D2). Table 3 and Figure 6 show the initial and final calcination temperatures and weight loss. The investigated limestones showed similar behavior in a pure $\mathrm{O}_{2}$ atmosphere, but with significant differences in the calcination temperature range. At higher $\mathrm{CO}_{2}$ concentration, the effect of the delay of the initial and final tem- peratures of calcination is evident. The weight losses for different limestones remained approximately constant at the different gas mixtures used but, in all cases, they were higher for $\mathrm{C}$ (Table 3 ). This limestone has a higher concentration of carbonates, and lower amount of impurities. On the contrary, the lowest weight loss is for $\mathrm{Cd}$ as a result of the presence of impurities $\left(\mathrm{SiO}_{2} \sim 21 \%\right.$; Table 2). Some minerals are inert to burning, such as quartz, but clay minerals present some weight loss due to structural water break up.

At higher $\mathrm{PCO}_{2}$ (partial pressure of $\mathrm{CO}_{2}$ ), the main effect observed for $\mathrm{Cd}$ and $\mathrm{D} 2$ was the appearance of a two-step decomposition pattern, which did not occur for $\mathrm{C}$. The separation between the peaks at $\sim 725$ and $\sim 925{ }^{\circ} \mathrm{C}$ is evident at $80 \% \mathrm{CO}_{2}$, as can be seen in Figure 6. The increase of $\mathrm{CO}_{2}$ concentration in the carrier gas results in a delay in the onset of the calcination temperature for $\mathrm{MgCO}_{3}$, but a stronger delay for $\mathrm{CaCO}_{3}$ and, as a result, the two endothermic peaks are well separated. More recent studies consider the decomposition of the dolomite mineral $\mathrm{CaMg}\left(\mathrm{CO}_{3}\right)_{2}$ in one step, with subsequent recarbonation of $\mathrm{CaO}$ to form $(\mathrm{Mg})$-calcite and the decomposition of $(\mathrm{Mg})$-calcite in a second step (RodriguezNavarro, 2012).

Therefore, from a practical point of view, the amount of impurities facilitates the calcination process: the higher the level of impurities the lower are the initial and final calcination temperatures. This was demonstrated in oxidizing conditions and at higher $\mathrm{PCO}_{2}$. As can be seen in Figures 3 and 4, impurities dilute the concentration of carbonate sites, which may favor calcination due to a lower local $\mathrm{CO}_{2}$ concentration at the reaction surface. The differences in calcination behavior of the limestones in industrial use must be considered to ensure the complete calcination according to the burning temperatures, as shown in Table 3.

Table 3: Initial and final calcination temperatures and weight loss in TGA / DTA in different reaction atmospheres. Cd, C and D2 limestones.

\begin{tabular}{|c|c|c|c|c|}
\hline Sample & Carrier gas & \multicolumn{2}{|c|}{$\begin{array}{c}\text { Calcination } \\
\text { temperatures }\left({ }^{\circ} \mathbf{C}\right)\end{array}$} & $\begin{array}{c}\text { Weight loss } \\
\text { (\%) }\end{array}$ \\
\cline { 3 - 4 } & & Initial & Final & \\
\hline \multirow{3}{*}{$\mathrm{Cd}$} & $\mathrm{O}_{2}$ & 384 & 804 & 33 \\
& $12 \% \mathrm{CO}_{2}+$ air & 432 & 840 & 32.7 \\
& $80 \% \mathrm{CO}_{2}+\mathrm{O}_{2}$ & 468 & 918 & 32.5 \\
\hline \multirow{3}{*}{$\mathrm{C}$} & $\mathrm{O}_{2}$ & 654 & 828 & 43 \\
& $12 \% \mathrm{CO}_{2}+$ air & 765 & 882 & 43 \\
& $80 \% \mathrm{CO}_{2}+\mathrm{O}_{2}$ & 868 & 953 & 43 \\
\hline \multirow{3}{*}{$\mathrm{D} 1$} & $\mathrm{O}_{2}$ & 564 & 810 & 36.7 \\
& $12 \% \mathrm{CO}_{2}+$ air & 636 & 860 & 37.9 \\
& $80 \% \mathrm{CO}_{2}+\mathrm{O}_{2}$ & 660 & 930 & 38 \\
\hline
\end{tabular}


(a)

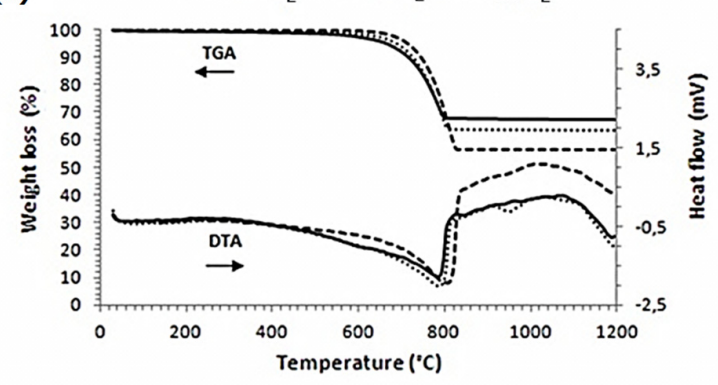

(b)

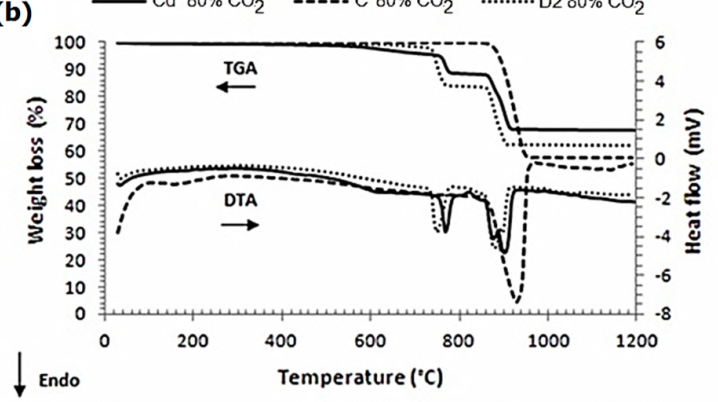

Figure 6: TGA/DTA curves for $\mathrm{Cd}, \mathrm{C}$ and $\mathrm{D} 2$ calcined in different atmospheres: (a) pure $\mathrm{O}_{2}$; (b) $80 \%$ $\mathrm{CO}_{2}+20 \% \mathrm{O}_{2}$.

The best temperature for maximum desulfurization of the flue gas will depend on the limestone type. Depending on the reactor temperature, reaction mechanisms of direct $\left(\mathrm{CaCO}_{3}\right)$ or indirect $(\mathrm{CaO})$ sulfation of the limestone may occur. It has been demonstrated that indirect sulfation reached the highest efficiency of desulfurization, so that operating temperatures must be regulated in order to promote this reaction, i.e., above $900{ }^{\circ} \mathrm{C}$ (reducing atmosphere) (De Diego, 2013ab; de Souza, 2013). Hence, complete calcination is a key factor for higher desulfurization efficiency. On the other hand, prolonged residence times in fluidized bed systems will lead to extensive decreases in the surface area and porosity of the particles, which inhibits limestone reactivity and diminishes sulfation efficiency (Stanmore, 2005).

Figure 7 shows the surface of a particle after the calcination of limestone $\mathrm{Cd}$ in the thermobalance at $80 \% \mathrm{CO}_{2}$. It can be assumed that the calcination is complete from $\sim 918{ }^{\circ} \mathrm{C}$, as evidenced by the TG curve (Figure 6). This sample has a different aspect compared to the limestone raw material (Figure 5), and has no direct relationship to the developed porosity, as cited before. At $1200^{\circ} \mathrm{C}$, it is easier to visualize the effect of burning temperature on the samples, due to prolonged sintering and the grain growth mechanism. Sintering occurred significantly, as highlighted in Figure 7. This is evidenced by the direct bonding between the grains, typically a solid-phase sintering (Reed, 1995). It can be noted that sintering leads to a reduction in porosity, but the sample still has open pores near to the zero porosity region. Accordingly, in oxy-combustion, an increase in temperature is required for complete conversion of limestone due to the delay in calcination temperature, as explained above. However, an increase in temperature may enhance sintering. It was also pointed out that the presence of $\mathrm{CO}_{2}$ in the gas phase promotes sintering (Stanmore, 2005). Therefore, the calcination temperature must be chosen carefully since it determines the pore structure of $\mathrm{CaO}$ formed, which in turn is directly related to the desulfurization efficiency ( $\mathrm{Hu}, 2008$; Chen, 2008). Calcination is also important in the determination of the best residence time of the sorbent in FBC (Scala, 2010). The morphology aspect of $\mathrm{C}$ is similar to $\mathrm{Cd}$, despite the higher amount of impurities of $\mathrm{Cd}$. Thus, the kind of impurities present in limestone $\mathrm{Cd}$ does not affect the behavior of $\mathrm{CaO}$ (or $\mathrm{MgO}$ ) grains in sintering. As shown before, impurities may be separated from $\mathrm{CaO}$ grains (Figures 3 and 4). The behavior shown in $\mathrm{C}$ and $\mathrm{Cd}$ particles indicates that sintering occurs in $\mathrm{CaO}$ grains, and almost independently of external impurities (out of the calcitic particle).
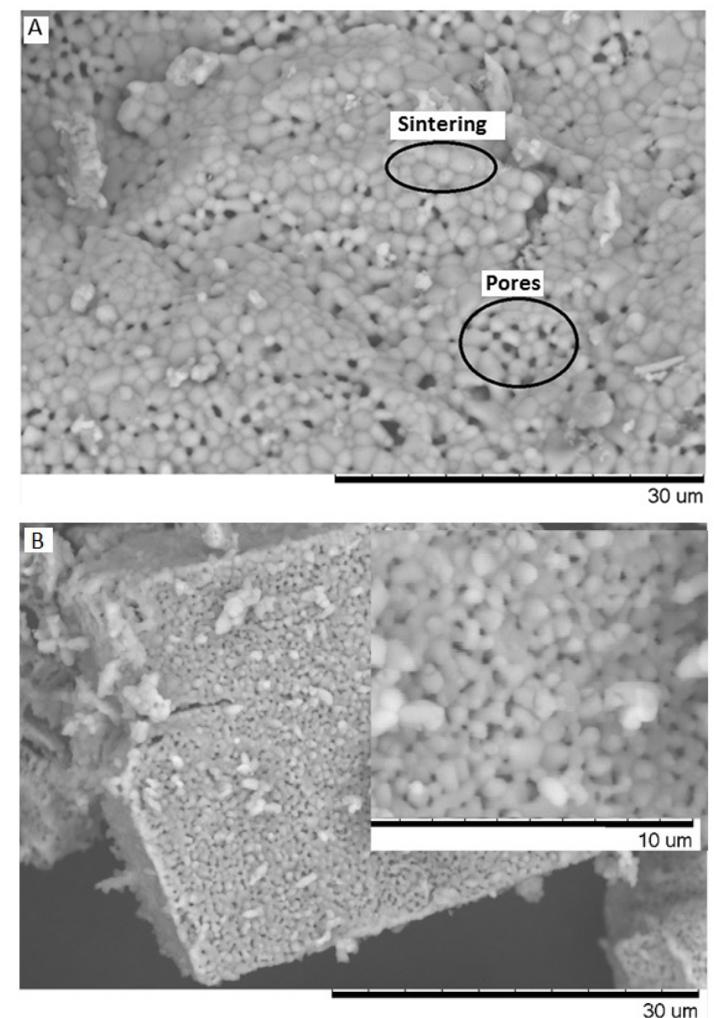

Figure 7: SEM of $\mathrm{Cd}(\mathrm{A})$ and $\mathrm{C}(\mathrm{B})$. Calcination at $80 \% \mathrm{CO}_{2}$ and $1200{ }^{\circ} \mathrm{C}$. 


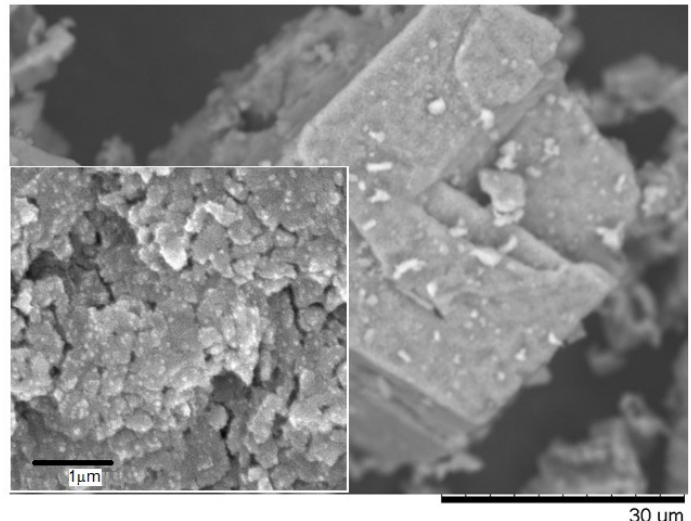

Figure 8: SEM of $\mathrm{C}$ limestone. Calcination temperature $850{ }^{\circ} \mathrm{C}$. Sintering can only be observed at higher magnification.

In Figure 8, it can be observed that sintering had already occurred at $850{ }^{\circ} \mathrm{C}$ even in the relatively pure limestone C. A cuboidal particle (width $=\sim 40 \mu \mathrm{m}$ ) consisting of grains of 200-300 nm shows submicron-particles or grain clusters, which are formed with grains linked to each other. This means that the particles shrunk upon calcination (Anthony, 2001).

Pore size and grain cluster sizes met those of published data. For example, Garcia-Labiano (2002) showed grain clusters of about $1 \mu \mathrm{m}$, and Laursen (2000) showed grains of 0.2-0.5 $\mu \mathrm{m}$. The aspect of microstructure and sintering behavior of the limestones studied are similar of those in the literature (Laursen, 2000; Cheng, 2004).

Therefore, the role of impurities is to accelerate sintering, but the most influential impurities are the ones in the carbonatic phase (intra- and intercrystalline), such as foreign ions, which promote lattice diffusion (Figure 4 shows a dispersion of ions throughout the microstructure). The presence of intrinsic defects and mainly extrinsic defects in the crystal structure would explain the sintering behavior of limestones in the calcination process due to the high melting temperature of calcium oxide.

\section{Evaluation of Limestones Do and D1 in FBC}

The results of the tests in the fluidized bed reactor (Figure 9) show that both limestones (Do and D1) had similar performance in desulfurization, despite their differences in chemical composition. They reached the same $\mathrm{SO}_{2}$ emission in milligrams per kilocalories, at a $\mathrm{Ca} / \mathrm{S}$ molar ratio of 3 . Therefore, it was possible to fit the emissions within the standards for large thermoelectric plants $(2 \mathrm{mg} / \mathrm{kcal})$ (CONAMA, 1990). In this case, the compositional differences between the two limestones did not influence the desulfurization process, since the amount of calcium oxide used in each test is the same equalized by the molar ratio. Both limestones reached $\sim 70 \%$ of desulfurization efficiency. Other results of the limestones from southern Brazil used in desulfurization on bench and pilot scale can be found in the works of one of the authors (Bragança, 2003, 2009; Sebag, 2001).

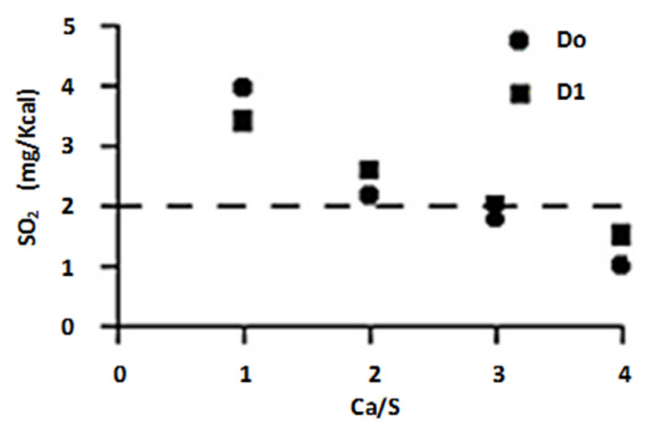

Figure 9: $\mathrm{SO}_{2}$ emissions as a function of $\mathrm{Ca} / \mathrm{S}$ molar ratio. D1 and Do limestones.

The main disadvantage of the use of limestone Do is the smallest amount of calcium oxide (Table 2). On a weight basis, it only achieves the same desulfurization efficiency obtained with D1 limestone if Do is added in larger amounts, approximately 1.5 times more. That means 10 t D1 limestone/100 t of coal; while Do needs $15 \mathrm{t} / 100 \mathrm{t}$ of coal. The same occurs in relation to energy consumption, considering sensible heat and calcination heat (calcination of limestone is a highly endothermic reaction; $\Delta \mathrm{H}=+182.1 \mathrm{~kJ} \mathrm{~mol}^{-1}$; Stanmore, 2005):

Energy consumption $=$ Mass of limestone

$$
\times\left(c p \times \Delta T+\Delta H_{\text {calcination }}\right)
$$

Consequently, a higher $\mathrm{MgCO}_{3}$ content, as occurs in Do, requires a larger volume of sorbent to obtain the same $\mathrm{Ca} / \mathrm{S}$ molar ratio. As a result, the use of dolomites results in some losses of energy and generates more solid waste. Nevertheless, the cost of Do as raw material usually is up to three times lower than that of calcitic limestones, which may have a cost quite close to the coal from open pit mining. Moreover, the price of transport is the variable determining the final cost and therefore the selection of a limestone. Thus, the better option for the desulfurization processes is to use the limestones closer to the thermoelectric plant, as already discussed in previous works (Anthony, 2001). This highlights the importance of the study of dolomitic limestones and, among them, the lowest cost limestones should also be chosen. 


\section{CONCLUSIONS}

The characterization of $\mathrm{Cd}$ (dolomitic limestone) with a high impurities content $(\sim 26 \%)$ showed that these impurities may be individual particles or may be in the same particle adjacent to the calcitic phase. During calcination, limestone particles undergo thermal shock, fragmentation, friction and the development of porosity as the decomposition proceeds, which may separate impurities from the calcitic phase. Consequently, the role of this kind of impurities, considering the way they are distributed in the studied limestone, may interfere very little in the calcination (and desulfurization) process. Thus, there is no need to remove them by mineral processing, and the limestone $\mathrm{Cd}$ can be employed in raw form (run of mine), manly in furnace conditions.

The analysis of the microstructure of $\mathrm{Cd}$ and $\mathrm{C}$ (calcitic limestone of high purity) revealed similarity in grain morphology. The presence of grain sintering was explained by the influence of microcrystalline impurities, dispersed in the microstructure, as can be seen in EDS mappings. Foreign ions occur frequently in the mineral formation and can increase the extrinsic defects concentration in the crystal structure, which promotes lattice diffusion and enhances sintering.

Tests in the thermobalance in an atmosphere of pure oxygen showed a similar profile in TGA/DTA curves, and differences in initial and final calcination temperatures of the limestones analyzed. At higher carbon dioxide concentrations, there are significant differences in the calcination curve. At $12 \% \mathrm{CO}_{2}$ (typical of boilers) the dolomite calcination occurs in a two-step pattern, which is clearer at $80 \% \mathrm{CO}_{2}$ (oxy-combustion), because the separation of peaks increases. Thus, a higher temperature in $\mathrm{a} \mathrm{CO}_{2}$ atmosphere is necessary for the calcination to take place completely $\left(\sim 50{ }^{\circ} \mathrm{C}\right.$ higher than in oxidizing conditions). Final calcination temperatures were approximately $20{ }^{\circ} \mathrm{C}$ to $30{ }^{\circ} \mathrm{C}$ lower for dolomitic limestones (D2 and $\mathrm{Cd}$, respectively); in comparison to limestone $\mathrm{C}$. The decomposition temperature depends on limestone purity and is favored by the amount of impurities. This can be an advantage for dolomitic limestones in terms of energy consumption.

The limestones studied here vary in chemical composition and other physical properties, but they have the same geological origin. Nevertheless, they showed similar desulfurization efficiency $(\sim 70 \%$ at $\mathrm{Ca} / \mathrm{S}=3$ ) in fluidized bed coal combustion. The results for the same $\mathrm{Ca} / \mathrm{S}$ molar ratio and strongly oxidizing atmosphere showed little influence of the impurities and the magnesium oxide content in the combustion gas desulfurization process. Dolomitic limestones require larger amounts on a weight basis (1.5 times more), relative to calcitic limestones to achieve the emission levels obligatory by regulatory standards. This means a penalty in terms of caloric consumption in the combustor. However, the lower cost of dolomites and their proximity to the thermoelectric plants may be the most important factors in the economic analysis.

\section{ACKNOWLEDGEMENT}

The authors acknowledge CNPq for the scholarship.

\section{REFERENCES}

Anthony, E. J., Granatstein, D. L., Sulfation phenomena in fluidized bed combustion systems. Progress in Energy and Combustion Science, 27, p. 215-236 (2001).

Bragança, S. R., Castellan, J. L., FBC desulfurization process using coal with low sulfur content, high oxidizing conditions and metamorphic limestones. Brazilian Journal of Chemical Engineering, 26(02), p. 375-383 (2009).

Bragança, S. R., Jablonski, A., Castellan, J. L., Desulfurization kinetics of coal combustion gases. Brazilian Journal of Chemical Engineering, 20(02), p. 161-169, (2003).

CGTEE, Companhia de Geração Térmica de Energia Elétrica - Eletrobras. <http://www.cgtee.gov.br> (2014). (In Portuguese).

Chen, J., Yao, H., Zhang, L., A study on the calcination and sulphation behaviour of limestone during oxy-fuel combustion. Fuel, 102, p. 386-95 (2012).

Chen, Z., Grace, J. R., Lim, C. J., Limestone particle attrition and size distribution in a small circulating fluidized bed. Fuel, 87, p. 1360-1371 (2008).

Cheng, L., Chen, B., Liu, N., Lou, Z., Cen, K., Effect of characteristic of sorbents on their sulphur capture capability at fluidized condition. Fuel, 83 p. 925-932 (2004).

CONAMA, Conselho Nacional do Meio Ambiente RESOLUÇÃO/N. ${ }^{\circ}$ 008. Brazilian Standards (Based on US-EPA) (1990). (In Portuguese).

CRM, CIA Riograndense de Mineração. <http:// www.crm.rs.gov.br> (2014). (In Portuguese).

De Diego, L. F., de Las Obras-Loscertales, M., Rufas, A., García-Labiano, F., Gayán, P., Abad, A., Adánez, J., Pollutant emissions in a bubbling fluidized bed combustor working in oxy-fuel operating 
conditions: Effect of flue gas recirculation. Applied Energy, 102, p. 860-867 (2013).

De Diego, L. F., Rufas, A., García-Labiano, F., de Las Obras-Loscertales, M., Abad, A., Gayán, P., Adánez, J., Optimum temperature for sulphur retention in fluidised beds working under oxy-fuel combustion conditions. Fuel, 114, p. 106-113 (2013).

de Souza, F., Bragança, S. R., Thermogravimetric analysis of limestones with different contents of $\mathrm{MgO}$ and microstructural characterization in oxycombustion. Thermochimica Acta, 561, p. 19-25, (2013).

Garcia-Labiano, F., Abad, A., de Diego, L. F., Gayan, P., Adanez, J., Calcination of calcium-based sorbents at pressure in a broad range of $\mathrm{CO}_{2}$ concentrations. Chem. Eng. Sci., 57, p. 2381-2393 (2002). In: Rodriguez-Navarro, C., Kudlacz, K., Ruiz-Agudo, E., (2012).

Han, K., Lu, C., Cheng, S., Zhao, G., Wang, Y., Zhao, J., Effect of characteristics of calcium-based sorbents on the sulfation kinetics. Fuel, 84, p. 19331939 (2005).

Hu, G., Dam-Johansen, K., Wedel, S., Hansen, J. P., Review of the direct sulfation reaction of limestone. Progr. Ener. Comb. Sci., 32, p. 386-407 (2006).

Hu, G., Dam-Johansen, K., Wedel, S., Oriented nucleation and growth of anhydrite during direct sulfation of limestone. Crystal Growth \& Design, 8(4), p. 1181-1185 (2008).

IPCC, Intergovernmental Panel on Climate Change. $<\mathrm{http}: / /$ www.ipcc.ch/> (2014).

Kaljuvee, T., Trikkel, A., Kuusik, R., Bender, V., The role of $\mathrm{MgO}$ in the binding of $\mathrm{SO}_{2}$ by lime containing materials. Journal Ther. Anal. Cal., 80(3), p. $591-597$ (2005).

Las Obras-Loscertales, M., Rufas, A., De Diego, L. F., García-Labiano, F., Gayán, P., Abad, A., Adánez, J., Effects of temperature and flue gas recycle on the $\mathrm{SO}_{2}$ and $\mathrm{NOx}$ emissions in oxyfuel fluidized bed combustor. Energy Procedia, 37, p. 1275-1282 (2013).

Laursen, K., Duo, W., Grace, J. R., Lim, J., Sulfation and reactivation characteristics of nine limestones. Fuel, 79, p. 153-163 (2000).

Luz, A. B., Lins, F. A., Freitas, F. Rochas \& Minerais
Industriais: Usos e Especificações (Rocks and Minerals: Uses and Specifications). Centro de Tecnologia Mineral, Rio de Janeiro (2005). (In Portuguese).

Montagnaro, F., Salatino, P., Scala, F., The influence of temperature on limestone sulfation and attrition under fluidized bed combustion conditions. Exp. Therm. Fluid Sci., 34, p. 352-358 (2010).

Moraes, F. C., Geological characterization of the gauchos marbles aiming its use as a desulfurizing agent of coal combustion gases. Master Thesis, Universidade Federal do Rio Grande do Sul, UFRGS-PPGEM, Brazil (1996).

Petijohn, F. J., Sedimentary Rocks. New York, Harper and Brothers (1957).

Reed, J. S., Principles of Ceramic Processing. 2nd Ed., John Wiley \& Sons, New York (1995).

Rodriguez-Navarro, C., Kudlacz, K., Ruiz-Agudo, E., The mechanism of thermal decomposition of dolomite: New insights from 2D-XRD and TEM analyses. Amer. Miner., 97, p. 38-51 (2012).

Scala, F., Salatino, P., Flue gas desulphurization under simulated oxyfiring fluidized bed combustion conditions: The influence of limestone attrition and fragmentation. Chemical Engineering Science, 65 , p. 556-561 (2010).

Sebag, M. G., Bragança, S. R., Jablonski, A., The behavior of heavy metals in the process of desulfurization of Brazilian coal combustion gases by addition of limestone. Brazilian Journal of Chemical Engineering, 18(2), p. 139- 147 (2001).

Stanmore, B. R., Gilot, P., Review-calcination and carbonation of limestone during thermal cycling for $\mathrm{CO}_{2}$ sequestration. Fuel Processing Technology, 86, p. 1707-1743 (2005).

Trikkel, A., Estonian calcareous rocks and oil shale ash as sorbents for $\mathrm{SO}_{2}$. $\mathrm{PhD}$ Thesis, Tallinn Technical University (2001). In: Stanmore, B. R., Gilot, P., Review-calcination and carbonation of limestone during thermal cycling for $\mathrm{CO}_{2}$ sequestration. Fuel Processing Technology, 86, p. 17071743 (2005).

Valverde, J. M., Sanchez-Jimenez, P. E., PerezMaquedab, L. A., Ca-looping for postcombustion $\mathrm{CO}_{2}$ capture: A comparative analysis on the performances of dolomite and limestone. Applied Energy, 138, p. 202-215 (2015). 